\title{
Diagnosing the Kaiser: Psychiatry, Wilhelm II and the Question of German War Guilt The William Bynum Prize Essay 2016
}

\author{
DAVID FREIS * \\ Institute for the History, Theory and Ethics of Medicine, University of Münster, \\ Von-Esmarch-Straße 62, 48149 Münster, Germany
}

\begin{abstract}
After his abdication in November 1918, the German emperor Wilhelm II continued to haunt the minds of his people. With the abolition of the lese-majesty laws in the new republic, many topics that were only discussed privately or obliquely before could now be broached openly. One of these topics was the mental state of the exiled Kaiser. Numerous psychiatrists, physicians and laypeople published their diagnoses of Wilhelm in high-circulation newspaper articles, pamphlets, and books shortly after the end of the war. Whether these diagnoses were accurate and whether the Kaiser really was mentally ill became the issue of a heated debate.

This article situates these diagnoses of Wilhelm II in their political context. The authors of these diagnoses - none of whom had met or examined Wilhelm II in person - came from all political camps and they wrote with very different motives in mind. Diagnosing the exiled Kaiser as mentally ill was a kind of exorcism of the Hohenzollern rule, opening the way for either a socialist republic or the hoped-for rule of a new leader. But more importantly, it was a way to discuss and allocate political responsibility and culpability. Psychiatric diagnoses were used to exonerate both the Emperor (for whom the treaty of Versailles provided a tribunal as war criminal) and the German nation. They were also used to blame the Kaiser's entourage and groups that had allegedly manipulated the weak-willed monarch. Medical concepts became a vehicle for a debate on the key political questions in interwar Germany.
\end{abstract}

Keywords: Wilhelm II (1859-1941), psychiatry, First World War, Weimar republic, political leadership, forensic medicine

\section{Introduction}

In the morning hours of 10 November 1918, the day after the proclamation of the German republic, Wilhelm II crossed the border in his imperial court train, leaving Germany for

* Email address for correspondence: david.freis@uni-muenster.de

I would like to thank Martin Kohlrausch and the three anonymous reviewers for their insightful and constructive feedback, which has helped me to considerably improve this manuscript. 
his exile in the Netherlands. He never returned, but neither did he leave the minds of his people. A few months later, the socialite, diplomat and 'red count' Harry Kessler (1868-1937) noted in his diary: 'This evening, [the diplomat Conrad Gisbert] Romberg came to dine with me in the Union club. We discussed his assignment to the Foreign Office and my idea for a league of nations. Later, [the composer Max von] Schillings joined us and spoke in his clownishly genial way about the Kaiser, about Roosevelt, etc. He most entertainingly characterised the Kaiser as a pathological figure. ${ }^{1}$ The alleged pathology of Wilhelm II was not just the table talk of Kessler's elite entourage, the topic also captured the attention of dedicated professionals. Immediately after the end of the war - and the de facto abolition of the lese-majesty legislation that would certainly have made most of these publications punishable before - several psychiatrists and physicians and some laypeople issued their diagnoses of Germany's exiled emperor. In numerous newspaper articles, pamphlets, contributions to medical journals and whole books, they pondered the alleged mental defects of the Kaiser and their political implications.

The depiction of Wilhelm II as an 'operetta character suffering from megalomania' has had a lasting impact on the public image of the last German emperor. ${ }^{2}$ Moreover, some of these writings have been also used by historians to support their portrayals of the personality of Wilhelm II, for example John C. G. Röhl, author of a considerable body of authoritative studies on the Kaiser's life, Nicolaus Sombart and Thomas A. Kohut. ${ }^{3}$ Understanding the defects of Wilhelm's personality, they suggest, means understanding the political actions of a key figure in the outbreak of the First World War. The question whether the Kaiser was a 'pathological figure' seems directly linked to the question of who was responsible for the global cataclysm of 1914-18. Therefore, the issue of Wilhelm II's alleged mental defects became part of the debate about the origins of the First World War; a topic that has since filled entire libraries and resurfaces periodically, most recently in the context of the centenary of the war and Christopher Clark's widely read account of how European diplomacy stumbled into an avoidable catastrophe, The Sleepwalkers. ${ }^{4}$ Although psycho-history is clearly not as fashionable as it once used to be, the step from metaphorical somnambulism to actual psychiatric diagnosis is apparently tempting, and the connection between the mental state of a major protagonist and the ensuing cataclysm seems intuitively compelling.

\footnotetext{
${ }^{1}$ Harry Kessler, Tagebücher 1918 bis 1937, ed. Wolfgang Pfeiffer-Belli (Frankfurt am Main: Fischer, 1996), 171. All translations from foreign languages by the author, unless stated otherwise.

${ }^{2}$ Martin Kohlrausch (ed.), Samt und Stahl: Kaiser Wilhelm II. im Urteil seiner Zeitgenossen (Berlin: Landt, 2006), 9. On the biography of Wilhelm II, see also Christopher Clark, Kaiser Wilhelm II (Harlow: Longman, 2000). For an overview of recent research, see Martin Kohlrausch, 'Zu Wilhelm II. noch etwas neues? Tendenzen der Forschung der letzten zwei Jahrzehnte', in Nicolas Detering, Johannes Franzen and Christopher Meid (eds), Herrschaftserzählungen: Wilhelm II. in der Kulturgeschichte (1888-1933) (Würzburg: Ergon, 2016), 19-37.

${ }^{3}$ The most explicit retrospective diagnoses of Wilhelm II by historians, published at the height of the psychohistory boom, can be found in John C. G. Röhl and Nicolaus Sombart (eds), Kaiser Wilhelm II: New Interpretations: The Corfu Papers (Cambridge: Cambridge University Press 1982); John C.G. Röhl, Kaiser, Hof und Staat: Wilhelm II. und die deutsche Politik (Munich: Beck, 1988), 17-34. More recently, Thomas A. Kohut, 'Mirror Image of the Nation: An Investigation of Kaiser Wilhelm II's Leadership of the Germans,' in Charles B. Strozier et al. (eds), The Leader: Psychological Essays (New York: Springer, 2011), 77-117. On psycho-history, see, for example, Peter Gay, Freud for Historians (Oxford: Oxford University Press, 1985). For a first attempt to place these sources in an historical context, see Sibylle Leider, 'Widersprüche überall: Wilhelm II. in psychiatrischen Beurteilungen nach 1918', Hans Wilderotter and Klaus-D. Pohl (eds), Der letzte Kaiser: Wilhelm II. im Exil (Gütersloh: Bertelsmann 1991), 150-56; see also Joachim Radkau, Das Zeitalter der Nervosität: Deutschland zwischen Bismarck und Hitler (Munich: Hanser, 1998).

${ }^{4}$ Christopher Clark, The Sleepwalkers: How Europe Went to War in 1914 (London: Penguin, 2013).
} 
Yet, using the historical diagnoses of Wilhelm II in this way is misleading. The main problem is that Röhl and other scholars have taken these documents at face value, isolated from their context of origin in both medical and political history. Although the medical authority of some of the authors seems to lend some weight to their assessments of the Kaiser, they do not stand as actual psychiatric diagnoses. None of these self-proclaimed experts ever met Wilhelm II in person, let alone conducted any kind of clinical examination that would allow for a diagnosis meeting contemporary or present-day standards. However, this article is not about the well-known shortcomings of psycho-history. Instead, I argue that these writings may tell us something about the political debates of the immediate postwar period and the Germans' difficulties in coping with the war, the defeat and the collapse of the monarchy. The numerous psychiatric diagnoses of Wilhelm II, in other words, may tell us less about the mind of the exiled emperor and more about post-war Germany's political and emotional 'culture of defeat', as medical concepts became part of a heated debate about the implications of the war and about the future of the German nation. ${ }^{5}$

What did it mean to diagnose the exiled emperor as mentally ill in post-war Germany? As I intend to show, finding out what these diagnoses signified in their specific historical context proves to be more complex than one might initially expect; a problem that is exacerbated by the fact that these writings cannot be situated in a single ideological camp. Quite the contrary, when assessing the mental state of the exiled emperor, leftwing socialist pacifists and jingoist right-wing nationalists came up with strikingly similar arguments. Of course, the most obvious interpretation would be to read these diagnoses as an attack on Wilhelm's public and political persona. Now as then, calling someone 'mad' or a 'psychopath' is one of the more strident ad hominem attacks that political rhetoric has to offer. While the explanatory value is usually more than questionable, political ideas are personalised and delegitimised as figments of a deranged mind and the target is effectively excluded from the sphere of legitimate politics. In post-war Germany, the diagnosis could thus be used to counter demands for Wilhelm's return to Germany and to open the political stage for new actors. This is, however, not the whole story. When the question of legal and moral culpability is raised - as it was in the case of the Kaiser by the allies and parts of the German public - psychiatric diagnoses may function as a defence rather than as an attack. There is a long-standing legal tradition that madness mitigates or fully suspends culpability, ${ }^{6}$ and this reasoning could also be applied to the question of who was to blame for the war that had devastated Europe. But in this case, the culpability did not just vanish into thin air, instead, the diagnoses of Wilhelm II were used as rhetorical tools by which responsibility for the war and the German defeat could be shifted and reallocated. Could a nation be blamed for the decisions taken by a mentally deranged monarch? And if the Kaiser had been weak-willed and prone to suggestion, who had pulled the strings? In short, the question of the mental defects of the Kaiser was in fact a vehicle for a debate about the issue of German war guilt.

And finally, one can invert the direction of the diagnosis. What does it tell not about the diagnosed, but about the diagnosticians? Apart from making a political argument disguised as a psychiatric one, the post-war diagnoses of Wilhelm II were also polemical writings fraught with emotion. The recourse to psychiatric concepts betrayed feelings

\footnotetext{
${ }^{5}$ Wolfgang Schivelbusch, The Culture of Defeat: On National Trauma, Mourning, and Recovery, trans. Jefferson Chase (New York: Metropolitan, 2003).

${ }^{6}$ For a broader historical perspective, see Michael Clark and Catherine Crawford (eds), Legal History in Medicine (Cambridge: Cambridge University Press, 1994).
} 
of disorientation and bewilderment about the political events of the previous years and months. Apparently, something irrational had happened and clinical psychiatry offered the concepts to make sense of unreasonable behaviour. Notably, at the same time, there was a parallel discussion going on in German newspapers and medical journals, with eminent psychiatrists explaining why the 1918/19 revolution had been led by dangerous psychopaths and how a nervous collapse of the nation's collective soul had prepared the ground for the defeat and the upheaval. ${ }^{7}$ The figure of the mad leader featured prominently in both debates, as did the corresponding image of a hoped-for 'true leader'.

Freudians might perhaps be inclined to recognise an oedipal struggle at play here. Psychoanalysts have routinely paralleled the psychological dynamics of political and family life with the monarch and the father holding a similar patriarchal position. Paul Federn (1871-1950), a loyal disciple of Sigmund Freud, coined the phrase of the 'fatherless society' in 1919 when describing the overthrow of political authority at the end of the war as a symbolic act of parricide. ${ }^{8}$ Writing in Vienna, the father figure Federn had in mind was of course the venerable Habsburg emperor Franz Josef, who had passed away in 1916 after an epochal reign of sixty-seven years, but parts of his analysis may also apply to his Hohenzollern counterpart. Being declared mentally ill was often perceived as a kind of 'civic death'. Could a psychiatric diagnosis of a monarch, even a recently exiled one, be a symbolic regicide? ${ }^{9}$

The following section of this article lays out some of the historical precedents for the psychiatric diagnosis of a German monarch, in particular, the 'Caligula' affair and the deposition of Ludwig II of Bavaria. I then move on to the First World War, when physicians and psychiatrists on the other side of the front lines published damning and polemical diagnoses of the German head of state to support their nations' war efforts. In sections IV, $\mathrm{V}$, and VI, the focus returns to post-war Germany, where psychiatric diagnoses of Wilhelm II emerged as a genre that was used by authors from all political camps to advance a range of different arguments about the political consequences of the alleged mental illness of the recently exiled emperor. In a brief conclusion, I ask what the case of Wilhelm II can tell us about the present, and argue that, although intuitively compelling, psychiatric diagnoses of political leaders are the result of a disputable confusion between different forms of normativity.

As this article shows, the post-war diagnoses of Wilhelm II defy a straightforward interpretation. I situate these writings in their historical context and examine how declaring the exiled emperor a 'lunatic' or 'psychopath' could be used to advance different and even contradictory political agendas. In particular, I show that the allegedly deranged mind of Wilhelm II became a metaphor for the political situation of post-war Germany, and that the diagnoses became a medium to discuss many of the pressing questions about who was to blame for the war, about the legitimacy of the last Hohenzollern emperor, and about the future of the German polity.

\footnotetext{
${ }^{7}$ David Freis, 'The psychiatrist as the leader of the nation: psycho-political expertise after the German Revolution 1918/19', in Joris Vandendriessche, Evert Peeters and Kaat Wils (eds), Scientists' Expertise as Performance: Between State and Society, 1860-1960 (London: Pickering \& Chatto, 2015), 81-98.

${ }^{8}$ Paul Federn, Zur Psychologie der Revolution: Die vaterlose Gesellschaft (Leipzig: Anzengruber, 1919).

${ }^{9}$ Hans Jakob Ritter, 'Bürgerlicher Tod: Von der Angst, gesund ins Irrenhaus eingesperrt zu werden', in Stefan Nellen, Martin Schaffner and Martin Stingelin (eds), Paranoia City: Der Fall Ernst B.: Selbstzeugnis und Akten aus der Psychiatrie um 1900 (Basle: Schwalbe, 2007), 63-78.
} 


\section{Sandals, Scandals and the Madness of Monarchs}

Before turning to the debate that erupted after the end of the First World War, it is important to note that the theme of the mad monarch was not without historical precedent. It will not be necessary to go back as far as Roman antiquity and Tacitus, who in his Histories lamented the furor principum that led to the burning of the Temple of Jupiter in AD 69. ${ }^{10}$ In modern Germany, the concept first reached a larger audience with a novel by Gustav Freytag (1816-95), Die verlorene Handschrift [The Lost Manuscript], published in 1864. Freytag, one of the most widely read German novelist of his time, translated Tacitus's concept as Cäsarenwahnsinn [Caesarean madness] and introduced it to the German language. ${ }^{11}$ In the last third of the nineteenth century, the figure of the megalomaniac emperor became a common topic in Germany, as novelists, psychiatrists and ancient historians discussed the mental disorders that had led Roman emperors such as Nero and Caligula to engage in their grotesque debaucheries and atrocities. ${ }^{12}$

In the historicist nineteenth century, ancient history and present-day politics seemed more closely related than they do today. The eminent historian Theodor Mommsen (1817-1903), for example, used his acclaimed multi-volume history of Rome to advance national-liberal politics in post-1848 Germany. ${ }^{13}$ However, it was the issue of the Caesarean madness that pushed Roman antiquity onto the political stage, when a 17-page treatise on the Roman emperor Caligula sparked off one of the largest public scandals in the history of the German Empire. The left-liberal pacifist and future Nobel peace prize laureate Ludwig Quidde (1858-1941) published Caligula, 'a study on Roman Caesarean madness' in 1894. ${ }^{14}$ Ostensibly, Quidde had written an historical and psychological study of the personality of the first-century Roman emperor, presenting Caligula as a megalomaniac, corrupted by the conditions of monarchist rule. However, Quidde's contemporaries in imperial Germany had no difficulties in deciphering the true message. Caligula was Wilhelm II in a Roman disguise and Quidde's booklet was not, or at least not only, a scholarly contribution to ancient history, it was also a thinly veiled condemnation of the rule of the Kaiser and the political culture of the German Empire. Caligula was intended as a provocation, but the intensity of the reaction was surprising nonetheless. It became Wilhelmine Germany's most circulated political pamphlet, quickly selling some 200000 copies. ${ }^{15}$ Quidde became a celebrity almost overnight, but the ensuing scandal also spelled the end of his academic career. Caligula was controversially discussed in the major newspapers and triggered the publication of a wave of other pamphlets. ${ }^{16}$

Historians have since discussed several reasons why Ludwig Quidde's short text caused such uproar. The implicit depiction of Wilhelm II as a decadent ruler on the brink of insanity must have struck a chord with his contemporaries. Quidde mocked Caligula's

\footnotetext{
${ }^{10}$ W. Hamilton Fyfe (ed.), Tacitus: The Histories, Vol. 2 (Oxford: Clarendon Press, 1912), 83.

11 Gustav Freytag, Die verlorene Handschrift: Roman in fünf Büchern (Leipzig: Hirzel, 1864).

${ }^{12}$ Hans Kloft, 'Caligula: Ludwig Quidde und der Cäsarenwahnsinn', in Bernd Effe and Reinhold F. Glei (eds), Genie und Wahnsinn: Konzepte psychischer Normalität und Abnormalität im Altertum (Trier: Wissenschaftlicher Verlag, 2000), 179-204: 188-94.

13 Theodor Mommsen, Römische Geschichte, 8 vols (Munich: dtv, 2001).

${ }^{14}$ Ludwig Quidde, Caligula: Eine Studie über römischen Cäsarenwahnsinn (Leipzig: Friedrich, 1894).

${ }^{15}$ Martin Kohlrausch, 'Medienskandale und Monarchie: Die Entwicklung der Massenpresse und die "große Politik” im Kaiserreich', in Jörg Requate (ed.), Das 19. Jahrhundert als Mediengesellschaft: Les médias au XIXe siècle (Munich: Oldenbourg 2009), 116-30: 122.

${ }^{16}$ See, for example, Gustav Dannehl, Cäsarenwahn oder Professorenwahn: Biographisch-historische Studie, 4th edn (Berlin: Pauli's, 1894); Caligula Quitte, Das Vermächtnis des Tacitus (Leipzig: Wild, 1896).
} 
theatrical appearances, his 'inappropriate passion for grandeur and extravagance', the 'gigantic construction projects' and the 'lust for military victories', and many readers easily recognised the eccentricities of the current German emperor in this portrayal. ${ }^{17}$ Apart from the obvious anti-monarchist polemic, wide-spread disappointment with the politics of the Kaiser played a considerable role. When Wilhelm II ascended the throne in 1888 at the age of 29, a spirit of optimism took hold of the German Empire, and the liberal members of the middle class in particular. As Quidde wrote about CaligulaWilhelm: 'The people cheered him, as the change of government went through all circles like a salvation; an era of reforms seemed to begin and more liberal ideas could circulate freely. ${ }^{18}$ The disillusionment began with the dismissal of Reich Chancellor Otto von Bismarck (1815-98) in 1890 and Wilhelm II's blundering and increasingly notorious interference in political matters big and small. ${ }^{19}$ Published four years after 'the dropping of the pilot', Quidde's Caligula was an expression of the German liberals' increasing alienation from the Kaiser. Yet, as Martin Kohlrausch has pointed out, the scandal would not have been possible without the simultaneous transformation of relations between the monarchy, the media and the emerging public sphere. Anticipating the self-referential dynamics of modern media scandals, the logic of the Caligula affair was essentially circular: what made Quidde's pamphlet truly scandalous was its enormous success, which would not have been possible without the media reactions in the first place. ${ }^{20}$

Although Quidde introduced the Caesarean madness as a 'specific form of mental illness', he had no interest in issuing a psychiatric diagnosis. There was no reference to medical authorities in the text and the question where Caligula's affliction might be found in a contemporary psychiatric textbook was secondary to Quidde's argument. The Caesarean madness was no medical issue caused by individual psychology or physiological anomaly, but a moral and political problem stemming from the conditions of political leadership: 'The Caesarean madness is the product of conditions that can only flourish due to the moral degeneration of monarchist nations, or at least of the upper classes, of which the closer entourage of the monarch consists. ${ }^{21}$ However, Quidde's pamphlet introduced a conceptual template on which the Kaiser's post-war diagnosticians could build.

Moreover, it is important to remember that in nineteenth-century Germany, the issue of royal insanity was not always confined to antiquity and political rhetoric. As the end of the reign of Ludwig II (1845-86) shows, a psychiatric diagnosis had in fact the power to dethrone a king. The king of Bavaria was deposed on 10 June 1886 after a psychiatric assessment had found him mentally ill and incapable of ruling. ${ }^{22}$ Three days later, he was found dead in Lake Starnberg, with the body of psychiatrist Bernhard von Gudden (1824-86), who had been the main author of the assessment, floating next to him. The exact circumstances of the double drowning remain somewhat murky, something Bavarian

\footnotetext{
${ }^{17}$ Quidde, op. cit. (note 14); John C.G. Röhl, 'The Emperor's New Clothes: a character sketch of Wilhelm II', in Röhl and Sombart, op. cit. (note 3), 23-62: 29-30.

18 Quidde, op. cit. (note 14), 4; Gabriele Dietze, 'Queering Willie: Wilhelminische Maskulinitäten und die Kaiser-Figuration', L'Homme, 22, 2 (2011), 95-112: 102-3.

${ }^{19}$ Martin Kohlrausch, Der Monarch im Skandal: Die Logik der Massenmedien und die Transformation der Wilhelminischen Monarchie (Berlin: Akademie, 2005); Norman Domeier, Der Eulenburg-Skandal: Eine Kulturgeschichte der Politik des späten Kaiserreichs (Frankfurt am Main: Campus, 2010).

${ }^{20}$ Kohlrausch, 'Medienskandale', op. cit. (note 15), 123.

${ }^{21}$ Quidde, op. cit. (note 14), 7.

${ }^{22}$ H. Häfner and F. Sommer, 'The Bavarian Royal Drama of 1886 and the Misuse of Psychiatry: New Results', History of Psychiatry, 24, 3 (2013), 274-91.
} 
monarchists who indulge in conspiracy theories do not tire of repeating. More importantly, the procedures leading to the dethronement of Ludwig II exemplify that, when a head of state was diagnosed as insane and unfit to rule, there could be no clear-cut distinction between medicine and politics. A medical and psychiatric diagnosis of a king's natural mind and body necessarily affected his political body as well. ${ }^{23}$

Furthermore, it is true that in the case of Ludwig II psychiatric experts were mobilised for dynastic and political motives rather than due to medical concerns. His deposition was a reaction to his way of ruling. Even today, he is well known for having had less interest in everyday politics than in Wagnerian bombast and extravagant architecture. Now the kitschy castles built during his reign attract millions of tourists to Bavaria each year; at the time of their construction, however, they were a considerable fiscal burden to the monarchy and the state. The king's neglect of his representational duties, his alienation from key political actors and growing debt eventually led Prince Luitpold (1821-1912) to instigate the procedures leading to dethronement. Psychiatry was used to dispose of the Wittelsbach king while preserving the institutional status quo, and avoiding criticism of the institution of monarchy as such. Consequently, the idea of a specific 'Caesarean' form of madness as a symptom of a structural problem of monarchic rule could not be applied in the case of Ludwig II, but when the mental state of Wilhelm II became a publicly debated topic three decades later, the memory of the Bavarian royal drama was still lingering in the background, due not only to its political impact, but also to the late Bernhard von Gudden's lasting prominence among German psychiatrists.

Unlike the somewhat clichéd figure of the delusional mental patient imagining himself as emperor, real monarchs were hardly a common sight in fin-de-siècle psychiatry. ${ }^{24}$ Epidemiologically speaking, however, this seems to have had less to do with the prevalence of mental disorders among crowned heads, and more with their small number relative to the general population. In the sixteenth century alone, close to thirty German dukes, landgraves, and counts and one Holy Roman emperor, were considered by contemporaries to be mad. ${ }^{25}$ Numerous other examples of allegedly insane monarchs can be found in later centuries as well as in other European countries. For Carl Pelman (1838-1916), a psychiatrist and former asylum director, the Caesarean madness was an occupational disease threatening monarchs - 'a psychosis, which, by its nature, was caused by the Caesarean vocation'. ${ }^{26}$ As Pelman claimed in a 1910 book on borderline states in psychiatry, the Caesarean madness would not develop without a pathological disposition, but in history it had mainly been a result of monarchic rule itself. Unchecked political power and an entourage of adulatory and sequacious courtiers and servants were the conditions leading to a psychosis manifesting itself in 'suspicion and guile, hypocrisy and

\footnotetext{
${ }^{23}$ Ernst Kantorowicz, The King's Two Bodies: A Study in Mediaeval Political Theology (Princeton, NJ: Princeton University Press, 1957).

${ }^{24}$ Laure Murat, L'homme qui se prenait pour Napoléon: Pour une histoire politique de la folie (Paris: Gallimard, 2011), 177-240.

${ }^{25}$ H. C. Erik Midelfort, Mad Princes of Renaissance Germany, 2nd edn (Charlottesville, VA: University Press of Virginia, 1999).

${ }^{26}$ Carl Pelman, Psychische Grenzzustände, 2nd edn (Bonn: Cohen, 1910), 92; Hans von Hentig, Über den Cäsarenwahnsinn: Die Krankheit des Kaisers Tiberius (Munich: Bergmann, 1924); Detlev von Zerssen, 'Der Cäsarenwahnsinn: Wahrheit oder Legende?', Fortschritte der Neurologie, Psychiatrie, 79, 3 (2011), 152-60. On Carl Pelman, see Linda Orth et al. (eds), 'Pass op, sonst küss de bei de Pelman': Das Irrenwesen im Rheinland des 19. Jahrhunderts (Bonn: Grenzenlos, 1994).
} 
pretence, to the most brutal externalisation of bloodthirstiness and cruelty'. This diagnosis could fit in seamlessly with contemporary orientalist tropes. The despotic orient was where the disease had always flourished, and it was Julius Caesar's import of eastern customs that had brought it to Rome. ${ }^{27}$ Pelman arrived in modern Germany only after a lengthy and colourful discussion of the mental abnormities of Roman emperors and Russian czars. The end of the rule of Ludwig II of Bavaria, he argued, was the unlikely example of a case of Caesarean madness in a constitutional monarchy, were most of the atrocities happened only in the monarch's imagination and in which the individual disposition outweighed the political framework. Pelman neither shared Quidde's audacity, nor his liberal and antimonarchist leanings. Wilhelm II was absent here and there is no indication that Pelman saw his text as a commentary on contemporary politics. However, he set the course for the post-war debate in several regards. He claimed the issue of the Caesarean madness for professional psychiatrists, he shifted the focus of the discourse from nurture to nature, and he anticipated the exculpatory function of the post-war debate when he argued that the fact that the mad emperors in history suffered from mental illness mitigated their culpability. 'To understand all is to pardon all', Pelman concluded. ${ }^{28}$

\section{The Chin of Franz Josef, the Arm of Wilhelm and the Nose of Cleopatra}

In the three decades of his reign, Wilhelm II repeatedly found himself at the centre of political scandals, caused by impulsiveness, erratic politics, inflammatory speeches and ham-fisted appearances on the international stage. Together with his personal eccentricities, the Kaiser's political blunders caused many contemporaries to wonder what was going on in the mind of the head of the German state. ${ }^{29}$ However, as the consequences of the Caligula scandal had shown, this was clearly not a suitable topic to be broached in public. Only after the outbreak of the First World War did speculations about the mental state of the German emperor begin to circulate again in printed form. However, for obvious reasons, this happened not in Germany, but on the other side of the front line, when psychiatry became embroiled in wartime polemics. Freud lamented in 1915 that even 'science has lost its sober impartiality; its embittered servants try to extract weapons from it to contribute to the fight against the enemy. The anthropologist has to declare the enemy inferior and degenerate, the psychiatrist must proclaim the diagnosis of his mental defects. ${ }^{30}$ Diagnosing the Kaiser became part of the 'war of words', in which European intellectuals supported the fighting troops by using scientific arguments as shells that could be lobbed at enemy nations. I will use two examples, from France and Italy respectively, to illustrate the principal arguments of the debate.

One the first and most widely read diagnoses of Wilhelm II to appear during the First World War was Augustin Cabanès's (1862-1928) Folie d'empereur, a tome of 460 pages that not only promised to pass a 'medical judgement' on the German emperor, but also to diagnose the whole Hohenzollern bloodline as a 'dynasty of degenerates'. ${ }^{31}$ The author

\footnotetext{
${ }^{27}$ Pelman, op. cit. (note 26), 93.

${ }^{28}$ Pelman, op. cit. (note 26), 116.

${ }^{29}$ Kohlrausch, Samt und Stahl, op. cit. (note 2); Röhl, 'The Emperor's New Clothes', op. cit. (note 17), 36-41.

${ }^{30}$ Sigmund Freud, 'Zeitgemäßes über Krieg und Tod (1915)', in Das Unbehagen in der Kultur und andere kulturtheoretische Schriften (Frankfurt am Main: Fischer, 2007), 133-62: 135.

${ }^{31}$ Augustin Cabanès, Folie d'Empereur: Une dynastie de dégénérés: Guillaume II jugé par la science (Paris: Michel, 1915). The book was positively review in the British Medical Journal and published as an Italian translation in the same year, 'A History of the Hohenzollerns', British Medical Journal, 2, 2852 (1915), 327-328.
} 
was a French physician, medical historian and prolific populariser, whose oeuvre revolved around the role of medicine and sickness in political history. Cabanès applied his familiar historical approach to the Hohenzollerns, recounting the entire history of the dynasty since the Middle Ages and relishing in the detailed description of the alleged physical and mental abnormalities of his protagonists. The current emperor Wilhelm II appeared late in the book, after more than 400 pages. For his portrayal of the Kaiser, Cabanès drew heavily on Quidde's Caligula, which the journal L'information had published as a timely French translation in December 1914. ${ }^{32}$ The scope of his diagnosis went well beyond Quidde's, as the physician Cabanès was interested not only in Wilhelm's behaviour, but also in his bodily deformations. Wilhelm's left arm, crippled due to perinatal complications, became the topic of lengthy elaborations; an aspect that was, notably, conspicuously absent from the diagnoses appearing in Germany after the end of the war. ${ }^{33}$

What was missing from Cabanès's argument was a link between body and mind. As Wilhelm's crippled arm was not congenital but the result of an injury received at birth, it hardly fitted the fashionable concept of degeneration touted in the book's title. The 'imperial ear' was a more promising object of study; the attached earlobe purportedly visible on some photographs being one of the 'anatomical stigmas of degeneration' listed by fin-de-siècle anthropologists. ${ }^{34}$ However, Cabanès had little evidence for this interpretation and speculated instead about a range of infections that might have caused Wilhelm's alleged otological troubles. Without a theory to connect soma and psyche, Wilhelm's body could offer no explanation for the character traits and motives guiding his political decision making. Alfred Adler's (1870-1937) concept of the 'inferiority complex', introduced in 1912, only became part of the debate about the mental state of Wilhelm II after the war had come to an end. ${ }^{35}$ In Cabanès's account the physical deformation of the German emperor had certainly more to do with medical sensationalism than with a stringent psychopathological diagnosis. After all, the main thrust of his argument was that Wilhelm II was where all the negative traits of the Hohenzollerns culminated: 'the brutality of the Soldier King [Frederick William I of Prussia], the amorality of the "great" Frederick, the pietism of Frederick William II, the hazy brain of Frederick William IV' ${ }^{36}$ Cabanès's diagnosis of the Hohenzollerns was a typical piece of wartime propaganda in the guise of historical and medical scholarship, supporting the French Army in their defence of civilisation against a nation of brutes and madmen.

The Italian psychiatrist Ernesto Lugaro (1870-1940) was more sceptical about the political implications that came with diagnosing Wilhelm II. ${ }^{37}$ Two months after the

${ }^{32}$ For a reprint of the French translation, see Ludwig Quidde, Caligula: Étude d'un cas de folie césarienne à Rome, trans. Gaston Moch (Paris: Alcan, 1928).

33 Cabanès, op. cit. (note 31), 414-28. This aspect was not entirely new; possible psychological consequences of the physical deformation had already been mentioned by Wilhelm's former tutor Georg Hinzpeter (1827-1907) in 1888, see Georg Hinzpeter, 'Kaiser Wilhelm II.: Eine Skizze nach der Natur gezeichnet (1888)', in Kohlrausch, Samt und Stahl, op. cit. (note 2), 41-56; see also John C.G. Röhl, Young Wilhelm: The Kaiser's Early Life, 1859-88 (Cambridge: Cambridge University Press, 1998).

34 Cabanès, op. cit. (note 31), 427; Daniel Pick, Faces of Degeneration: A European Disorder, c. 1848-c. 1918 (Cambridge: Cambridge University Press, 1989).

35 Observator, Über die Nervosität im deutschen Charakter: Entwurf zu einer Analyse der deutschen Volksseele von der Reichsgründung bis zum Zusammenbruch (Leipzig: Der Neue Geist, 1922), 15; Alfred Adler, Über den nervösen Charakter: Grundzüge einer vergleichenden Individual-Psychologie und Psychotherapie (Wiesbaden: Bergmann, 1912), 9-29.

36 Cabanès, op. cit. (note 31), 450.

${ }^{37}$ Guiseppe Armocida and Jutta M. Birkhoff, 'Lugaro, Ernesto', Dizionario Biografico degli Italiani (2006), http://www.treccani.it/enciclopedia/ernesto-lugaro_(Dizionario-Biografico); Andrea Scartabellati, 'Il dovere dei 
kingdom of Italy had entered the war on the side of the Entente powers in late August 1916, he used an extensive editorial in the Rivista di Patologia nervosa e mentale to ponder the question whether German and Austro-Hungarian politics were caused by an individual 'madness of the emperor' or a collective 'national aberration'. ${ }^{38}$ It was not as if Lugaro generally disagreed with Cabanès. He found the German Kaiser to be physically, mentally and morally defective, and held the same to be true for his Austro-Hungarian counterpart Franz Josef. That Lugaro included the Habsburg emperor in his deliberations is not surprising, as the Italian troops were facing the Austro-Hungarian army along the hard-fought Isonzo front. The diagnosis of Franz Josef, however, differed considerably from that of Wilhelm II. Franz Josef was known for being dull rather than impulsive, and his old age allowed for speculations about dementia. Moreover, unlike Wilhelm's arm, the characteristic protruding chin of the Habsburgs, immortalised on numerous portraits since the early modern period, could easily be interpreted as a sign of hereditary degeneration. As successor of Cesare Lombroso (1835-1909) as chair of psychiatry in Turin, Lugaro was certainly familiar with the theories of the Italian school of 'positivist criminology' with its focus on the links between physical signs of degeneration and deviant, criminal and political, behaviour. ${ }^{39}$ Nevertheless, his argument took another direction.

Lugaro rejected Cabanès's and others' jump from medical diagnosis to political conclusion. Questioning whether the deformities of the Habsburg and Hohenzollern emperors could really influence the course of history in the way the previous diagnoses implied, he alluded to Blaise Pascal's (1623-62) famous counterfactual: 'The chin of Franz Josef and the arm of Wilhelm count nothing against the nose of Cleopatra.' ${ }^{40}$ Lugaro was concerned that the fixation on the personal defects and role of the emperors might obfuscate the real causes of the war, and that, contrary to their intended function, these diagnoses might actually entail an exculpation of the enemy nations. Blaming the emperors was 'a dangerous mistake, because it tends to veil the true responsible, who is not a man, but a nation, the German one'. ${ }^{41}$ While shifting the debate from the individual to the collective, Lugaro nevertheless remained inside the realm of psychiatric diagnosis. Like many psychiatrists of his time he firmly believed in the possibility of collective neurosis, transmitted from a charismatic individual to a larger group of people through a somewhat opaque process of suggestion. But this was not enough to explain the current political situation: ${ }^{42}$ "The national infatuation of the Germans is of another nature: less severe from the psychiatric point of view, but far worse concerning the social and political consequences'. ${ }^{43}$ The German nation, Lugaro argued, had over the course of centuries developed a striving for hegemony, which had all the characteristics of a collective mental illness, and was reinforced by generations of reciprocal suggestion. And like a mental

medici italiani nell'ora presente: Biopolitica, seduzione bellica e battaglie culturali nelle scienze umane durante il primo conflitto mondiale', Medicina \& Storia (2011), http://www.fupress.net/index.php/mes/article/view/103 86/9660.

${ }^{38}$ Ernesto Lugaro, 'Pazzia d'imperatore o aberrazione nationale?', Rivista di Patologia nervosa e mentale, 20, 7 (1915), 385-414.

39 Armocida and Birkhoff, op. cit. (note 37); Trevor Calafato, 'Gli anarcisti and Lombroso's theory of political crime', in Paul Knepper and P.J. Ystehede (eds), The Cesare Lombroso Handbook (New York: Routledge, 2013).

${ }^{40}$ Lugaro, op. cit. (note 38), 409. 'Le nez de Cléopâtre, s'il eût été plus court, toute la face de la terre aurait changé.' Blaise Pascal, Pensées (Paris: Gallimard, 1977), 243.

${ }^{41}$ Lugaro, op. cit. (note 38), 410.

42 Gustave Le Bon, Psychologie des Foules, 2nd edn (Paris: Alcan, 1896); Vladimir M. Bechterev, Die Bedeutung der Suggestion im sozialen Leben (Wiesbaden: Bergmann, 1905).

${ }^{43}$ Lugaro, op. cit. (note 38), 410. 
patient who was a threat to society, Germany had become a dangerous nation and a threat to its neighbours. ${ }^{44}$

\section{Madness as a Political Metaphor}

The moment the Kaiser left Germany, the questions about his mental state returned. The weeks and months after the armistice saw the publication of numerous treatises discussing the sanity of the exiled emperor. The idea that Wilhelm II suffered from a mental disorder was discussed in party newspapers, professional journals, widely circulated books and obscure brochures, and it occupied well-established psychiatrists and laypeople alike. As I intend to show, the reason that the mental state of Wilhelm continued to haunt the German public after his flight to the Netherlands was that the topic offered a way to discuss the key questions of the post-war period: Who was to blame for the war, who was to blame for the German defeat and how should the victors treat the vanquished? The mind of Wilhelm II became a metaphor for Germany's political situation, and like every successful metaphor, it could be read in a variety of ways.

The first post-war diagnosis of the exiled Kaiser to be published in Germany had in fact been written in neutral Switzerland. On 22 and 23 November 1918, Auguste Forel (1848-1931) published a two-piece article in Vorwärts, ${ }^{45}$, the newspaper of the German Social Democrats, who after decades in opposition were now in control of the interim postwar government, the Council of the People's Deputies, but split into a centrist and a leftwing socialist party. During the war, its newspaper had swayed between the majority and the left wing of the party, and in January 1919, the publishing building would become the site of violent clashes between Spartacist revolutionaries and right-wing Freikorps militias supporting the government. ${ }^{46}$ That Forel, who had acquired international renown as a psychiatrist, myrmecologist and social reformer, chose Vorwärts to publish his thoughts about the mental state of Wilhelm II and German politics was a logical consequence of both the German Social Democrats' long-standing quarrels with the emperor and Forel's own anti-monarchist and left-wing political views. Forel was an avowed socialist who had joined the Social Democratic Party of Switzerland in 1916. He also was a devout believer in scientific progress and a resolute internationalist and pacifist, who soon after the outbreak of the First World War had published his programme for an Esperantospeaking, teetotal, post-religious and demilitarised world society with radical eugenics. ${ }^{47}$ At the core of Forel's rampant political ideas stood the belief that scientific objectivity, and the understanding of the human brain in particular, could lead the way to an enlightened utopia. ${ }^{48}$ A similar translation of psychiatric authority into political expertise was also at work in his diagnosis of Wilhelm II.

${ }^{44}$ Lugaro, op. cit. (note 38), 412-13.

45 Auguste Forel, 'Verhängnisse: I. Bismarck und die Psychologie Wilhelms II', Vorwärts, 35, 321 (1918);

Auguste Forel, 'Verhängnisse: II. Deutschland, Europa und der Weltkrieg', Vorwärts, 35, 322 (1918). One week later, Forel republished the same article for a Swiss audience: Auguste Forel, 'Verhängnisse', Centralschweizerischer Demokrat (28/29 November 1918).

${ }^{46}$ Hermann Schueler, Trotz alledem: Der Vorwärts: Chronist des anderen Deutschland (Berlin: vorwärts buch, 2006).

${ }^{47}$ Auguste Forel, Die Vereinigten Staaten der Erde: Ein Kulturprogramm (Berne: Volkart \& Peytrequin, 1914). On Forel's biography, see Auguste Forel, Rückblick auf mein Leben (Zurich: Europa, 1935); Anton Leist (ed.), Auguste Forel: Eugenik und Erinnerungskultur (Zurich: vdf, 2006).

${ }^{48}$ Mirjam Bugmann, Hypnosepolitik: Der Psychiater August Forel, das Gehirn und die Gesellschaft (1870-1920) (Vienna: Böhlau, 2015). 
Auguste Forel's diagnosis was based on his authority as a renowned psychiatrist rather than on actual medical evidence. Without the possibility of a physical or psychological examination, Forel had to rely on hearsay and anecdotes, including a caricature in 'a humorous Viennese paper, whose name I have forgotten' ${ }^{49}$ This was a rather shaky foundation for a diagnosis, but it did not stop him from confidently declaring that Wilhelm II was 'unbalanced, impulsive, psychically abnormal', suffering from 'affective megalomania' and to be 'pitied as a congenitally abnormal person, but incurable'. ${ }^{50}$ Even the origin of the sickness was no mystery to Forel, who claimed that the bloodline of the Hohenzollern had been spoiled when it was 'mixed with the blood of an English princess', that is, Wilhelm's mother Victoria, Princess Royal (1840-1901). ${ }^{51}$ This was a very convenient argument, repeated in several other diagnoses of Wilhelm. It allowed to detach the discussion of Wilhelm's hereditary pathology from the rest of the Hohenzollern dynasty, while at the same time identifying the source of the illness as someone both foreign and female.

The political thrust of the argument became more visible in the second part of the article. ${ }^{52}$ Like Ernesto Lugaro, Forel used the elusive concept of 'suggestion' to bridge the individualising perspective of clinical psychiatry and the collective dimension of politics, connecting the mental life of the emperor and the nation. In Forel's analysis, Wilhelm II was both suggestive and suggestible; able to fascinate and dazzle the masses, while at the same time weak-willed enough to be easily influenced and guided himself. If the mentally unstable monarch could be swung like a hypnotist's pendulum, the diagnosis of his illness prompted questions about who had held the string. Speculations about a secretive 'camarilla' manipulating Wilhelm from behind the scenes of the imperial court had already been voiced during the Eulenburg scandal of $1906-09 .{ }^{53}$ A decade later, Forel reframed this narrative as a psychiatric diagnosis, while at the same time linking it to the question of German war guilt and rounding up his usual suspects, including 'Junkers, military leaders, big capitalists and industrialists, bureaucrats and professors, holders of decorations and titles, pensioners ..., the pan-German clique .... and many others, not to forget a number of clergymen'. Using the Kaiser as a front, this group created a state of 'megalomaniac, affective suggestion' and plunged the docile German people into phantasies of world domination and aggressive expansion. ${ }^{54}$

By sweepingly blaming elites and interest groups, Forel exculpated the German nation. An entire people, especially one as conscientious and devoted to duty as the Germans, Forel claimed, could not have recognised the pathology of Wilhelm II. Those individuals who were aware of the situation remained silent for fear of being imprisoned and the industrial and economic boom in the early years of Wilhelm's rule prevented any major public dissent. Thus, the German nation could not be held accountable for the war and its ramifications. As Forel saw it, his psychiatric diagnosis of Wilhelm had direct political consequences for the post-war order. The French, British and Americans would have to give up their desire for revenge on the vanquished but blameless Germans and instead

\footnotetext{
${ }^{49}$ Forel, 'Verhängnisse I', op. cit. (note 45).

50 Ibid.

51 Ibid.

${ }^{52}$ Forel, 'Verhängnisse II', op. cit. (note 45).

${ }^{53}$ Kohlrausch, op. cit. (note 19), 186-201; Domeier, op. cit. (note 19); Isabel V. Hull, The Entourage of Kaiser Wilhelm II, 1888-1918 (Cambridge: Cambridge University Press, 1982).

${ }^{54}$ Forel, 'Verhängnisse II', op. cit. (note 45).
} 
work to prevent a future repetition of the catastrophe by creating a truly democratic, global league of nations. ${ }^{55}$

Diagnosing Wilhelm II soon became a short-lived but popular genre of its own. Among the many books, articles and pamphlets printed in quick succession, one slim booklet stood out. Die Krankheit Wilhelms II. [The illness of Wilhelm II'] quickly sold over 18000 copies in four editions and attracted so much public attention that the author, Paul Tesdorpf (1858-1936), soon published a second booklet with open letters addressing some of the criticism. ${ }^{56}$ Tesdorpf was a largely unknown physician and dabbling poet from Munich, lacking the credentials of a renowned psychiatrist like Forel to bolster his claims. Apart from the wish to render his argument accessible for a lay audience, establishing his role as a psychiatric expert was probably the reason why he spent more than a dozen pages on a lengthy discussion of the general concept of mental illness. ${ }^{57}$ Moreover, Tesdorpf named Hubert von Grashey (1839-1914) and Bernhard von Gudden as his teachers; both eminent Bavarian psychiatrists of the late nineteenth century, as well as authors of the medical assessment that had led to the dethronement of Ludwig II in $1886 .{ }^{58}$ After establishing his medical authority, and on the basis of some anecdotes, Tesdorpf presented his diagnosis of the exiled emperor. Wilhelm II, he claimed, was a typical case of 'hereditary mental degeneration' and suffered from 'periodic insanity' (periodisches Irresein), oscillating between normality and phases of intense agitation or depression. ${ }^{59}$

Paul Tesdorpf clearly had another audience in mind than Auguste Forel, and, although similar in many aspects, his diagnosis of the Kaiser had very different political implications. The publishing house of Julius Friedrich Lehmann (1864-1935), where both of his booklets appeared, was the link between Germany's medical establishment and far-right nationalists. Lehmann published medical literature like the high-circulation Münchener Medizinische Wochenschrift [Munich medical weekly] as well as nationalist and anti-Semitic tracts, and used his role as a leading medical publisher to popularise eugenics and racial hygiene and to subsidise other nationalist works. ${ }^{60}$ As a 'fervent ultranationalist' he was a central part of the völkisch scene in post-war Munich, from which the National Socialist Workers' Party emerged, and a member of several paramilitary organisations. ${ }^{61}$ In the aftermath of the First World War, Lehmann began to peddle stabin-the-back conspiracy lore with numerous publications claiming that the German army had remained unvanquished and that the nation had been betrayed by Jews and Bolshevists.

55 Ibid.

${ }^{56}$ Paul Tesdorpf, Die Krankheit Wilhelms II. (Munich: J.F. Lehmann, 1919); Paul Tesdorpf, Offene Briefe über Die Krankheit Wilhelms II. (Munich: Lehmann, 1919). For contemporary reviews and reactions, see Adolf Hoppe, 'Die Krankheit Wilhelms II.: Kritische Bemerkungen', Psychiatrisch-Neurologische Wochenschrift, 21, 1/2 (1919), 5-7; Franz Kleinschrod, Die Geisteskrankheit Wilhelms II.? Eine Erwiderung (Wörishofen: Neuwihler, 1919); Adolf Hoppe, 'Noch einmal: Die Krankheit Kaiser Wilhelms II', Psychiatrisch-Neurologische Wochenschrift, 21, 41/42 (1920), 317-9. Other notable publications include Hermann Lutz, Wilhelm II. periodisch Geisteskrank! Ein Charakterbild des wahren Kaisers (Leipzig: Hillmann, 1919); Hans Wilm, Wilhelm II. als Krüppel und Psychopath (Berlin: Gerhard, 1920).

57 Tesdorpf, Die Krankheit, op. cit. (note 56), 1-16.

58 Ibid., 14.

${ }^{59}$ Ibid., 21, 29.

${ }^{60}$ Paul Weindling, 'The medical publisher Julius Friedrich Lehmann and the racialising of German medicine', in Sigrid Stöckel (ed.), Die rechte Nation und ihr Verleger: Politik und Popularisierung im J.F. Lehmanns Verlag 1890-1979 (Munich: Lehmanns Media, 2002).

${ }^{61}$ Ibid., 168. On the political and intellectual situation in post-war Munich and Germany, see Martin H. Geyer, Verkehrte Welt: Revolution, Inflation und Moderne: München 1914-1924 (Göttingen: Vandenhoeck \& Ruprecht, 1998); Richard Bessel, Germany after the First World War (Oxford: Clarendon Press, 1993). 
A psychiatric diagnosis of Wilhelm II, with its potential to divert the responsibility for the war away from the German nation and the responsibility for the defeat away from the army and the generals, could fit well in this agenda.

Auguste Forel had used the diagnosis of Wilhelm II to attack the monarchy and the Wilhelmine elites; Paul Tesdorpf used it to defend the emperor. In the preface to Die Krankheit Wilhelms II., signed the same day Forel published his Vorwärts article, Tesdorpf presented his diagnosis as an act of loyalty to the Kaiser. Wilhelm was to blame for the war, but his moral and political guilt was mitigated by his mental illness. ${ }^{62}$ Despite a considerable amount of pathos, Tesdorpf's political position is difficult to discern; as some references to 'free citizens' and the idea that all power should emanate from the people suggest, he most likely held national liberal views. ${ }^{63}$ His publisher, however, had little qualms about hijacking his author's argument for his own political agenda. In a foreword to the second booklet published in September 1919, Lehmann personally defended the diagnosis and his decision to publish it against the criticism from 'various sides', while at the same distancing himself from Tesdorpf's political views. ${ }^{64}$ As Lehmann claimed, the people had to know about the mental state of Wilhelm to understand 'that it is not monarchy as such that is an untenable condition, but that it is only untenable when there is a man at the top who does not have the mental powers necessary to hold such a heavy office'. ${ }^{65}$ In the hands of the ultra-nationalist publisher, diagnosing the monarch was a way to defend the monarchist status quo ante. By personalising the political responsibility for the war and the German defeat, one could avoid talking about the shortcomings of the pre-1914 political system. Anyway, Lehmann was convinced that democracy offered no alternative. He believed that the revolutionary post-war government of Bavaria, which had been ousted in May 1919 after heavy and brutal fighting with loyal elements of the German army and Freikorps, had consisted of 'nothing but mentally ill men' ${ }^{66}$

\section{Courtroom Psychiatry, International Politics and the Question of War Guilt}

Diagnosing the Kaiser could be used to mitigate and to reallocate political and moral responsibility. During the war, the Italian psychiatrist Ernesto Lugaro had warned his colleagues that focusing on Wilhelm's mental illness might be poorly suited as an argument for wartime propaganda, as it obfuscated the role of the German nation. Physicians like Auguste Forel and Paul Tesdorpf tried to achieve exactly this when they used the exiled emperor's alleged mental illness to personalise and mitigate Germany's responsibility for the war. However, the debate about the Kaiser's illness and culpability could also be framed in the more traditional form of an insanity plea. The German criminal code of 1871 , like the legal traditions of many other countries, stipulated that no criminal offence had been committed if the defendant had been in 'a state of unconsciousness or pathological disorder of mental activity' at the time of the act. ${ }^{67}$ As part of the professionalisation of psychiatry in the second half of the nineteenth century, Section 51 created the legal basis for the increasing presence of psychiatrists as medical experts in German courts, and for the emergence of forensic psychiatry and criminology

\footnotetext{
${ }^{62}$ Tesdorpf, Die Krankheit, op. cit. (note 56), 3-4.

63 Ibid., 34-35.

${ }^{64}$ Julius F. Lehmann, 'Vorwort', in Tesdorpf, Offene Briefe, op. cit. (note 56).

65 Ibid., 4.

${ }^{66}$ Ibid., 5.

${ }^{67}$ Strafgesetzbuch für das Deutsche Reich (Berlin: Nauck, 1871), Section 51.
} 
as distinct disciplines. ${ }^{68}$ When Paul Tesdorpf and his publisher Julius Friedrich Lehmann presented the diagnosis of Wilhelm's mental illness as evidence against his personal guilt for the First World War, they positioned themselves as self-appointed experts in a trial of the exiled emperor. ${ }^{69}$

At the time, putting Wilhelm II on trial seemed a real possibility. The Kaiser stood accused not only in the court of public opinion, but also by the victorious powers. The Treaty of Versailles, signed on 28 June 1919, provided for an international tribunal against Wilhelm II 'for a supreme offence against international morality and the sanctity of treaties.$^{70}$ As the Netherlands refused to extradite the Kaiser, the tribunal never took place. Nevertheless, Article 227 of the treaty marked a momentous shift in international law. For the first time, a head of state was to be held personally responsible for war crimes in front of an international court. ${ }^{71}$ The treaty introduced a new concept of personal culpability to international criminal law that set a precedent for institutions like the International Criminal Court in The Hague. To some extent, the psychiatric diagnoses of the Kaiser, although commissioned neither by the tribunal nor the defendant, followed a similar understanding of personal war guilt.

However, this kind of psychiatric exculpation was ambiguous. It made it possible to mitigate both the Germans' and Wilhelm's personal responsibility for the war, but, as a kind of collateral damage, also attacked the image and legitimacy of the last Hohenzollern emperor. As the example of the journal Irrenrechts-Reform [Reform of lunacy law] illustrates, critics of psychiatry were particularly sensitive to this doubleedged function of psychiatric diagnoses. The journal was the mouthpiece of the Bund für Irrenrecht und Irrenfürsorge) [Association for Lunacy Law and Lunatics Welfare], which was at the centre of a Wilhelmine 'anti-psychiatric' movement avant la lettre. ${ }^{72}$ Despite fierce polemics in the fight against unlawful confinement and disenfranchisement, the association was part of a bourgeois public and stayed clear of the left-wing politicisation that became characteristic for anti-psychiatry in the second half of the twentieth century. In the aftermath of the First World War, however, the movement temporarily embraced a revolutionary rhetoric, conflating the criticism of psychiatric power with attacks against the toppled Hohenzollern monarchy and calling for another revolution against the 'imperialists of psychiatry'. ${ }^{73}$ Unsurprisingly, psychiatrists' attempts to use their professional authority for an insanity defence of Wilhelm II were not well received in the Irrenrechts-Reform. Whatever opinion one might have about the mental state of the former emperor, an article in the journal stated, 'it won't do that such a man, who fell from godlike heights, is suddenly scientifically "labelled as a lunatic", just to minimise or conceal his complicity in the war'. ${ }^{74}$ And it was not just the political instrumentalisation of psychiatry in the defence

68 Richard F. Wetzell, 'Psychiatry and Criminal Justice in Modern Germany, 1880-1933', Journal of European Studies, 39, 3 (2009); Ruth Harris, Murders and Madness: Medicine, Law, and Society in the Fin de Siècle (Oxford: Oxford University Press, 1989).

${ }^{69}$ Lehmann, op. cit. (note 64), 4.

70 The Treaty of Peace between the Allied and Associated Powers and Germany (London: His Majesty's Stationery Office, 1919), 100.

71 David Crowe, War Crimes, Genocide, and Justice: A Global History (New York: Palgrave Macmillan, 2014), 79-114.

72 Heinz-Peter Schmiedebach, 'Eine “antipsychiatrische Bewegung” um die Jahrhundertwende', in Martin Dinges (ed.) Medizinkritische Bewegungen im Deutschen Reich (ca. 1870-ca.1933) (Stuttgart: Steiner, 1996), 127-60.

73 'Revolution im Irrenwesen', Die Irrenrechts-Reform, 62 (1919), 160-1.

74 'Wilhelm II. geisteskrank?', Die Irrenrechts-Reform, 62 (1919), 171-3. 
of the ancien régime that irked the anonymous writer, but also the fact that Wilhelm II had become a victim of illicit psychiatrisation: 'It requires a pathetic kind of courage to give the toppled ruler, the unfortunate, homeless fugitive, such a

The ambivalence of the psychiatric diagnosis, oscillating between stigmatisation and exculpation, mirrored the conflicting emotions of the German public. One the one hand, many who had rejected the Hohenzollern monarchy before, or had grown disillusioned during war and defeat, saw Wilhelm II as the main symbol of an outdated political order that had to be overcome. On the other hand, the accusations of war guilt against Wilhelm and the Germans and the strictures imposed by the victorious powers were widely perceived as unjust and duplicitous, and the projected trial against the former emperor as an illegitimate act of victors' justice. The psychiatric diagnoses of Wilhelm could not neutralise this tension, but they offered a conceptual frame that could contain both the need to symbolically exorcise the Hohenzollern monarchy and to morally defend the German nation.

In the spring of 1919, the Austrian-born neurologist Adolf Friedländer (1870-1949) self-consciously argued that his 'psychological analysis' of the Kaiser followed a triple rationale. ${ }^{76}$ First, Friedländer believed, his diagnosis answered a 'psychological and spiritual need' shared by 'every thinking German, be he monarchist or republican'. Understanding the Kaiser's psychology meant understanding his mutual relation with the German people, and thus was necessary to 'mentally overcome the Kaiser, the Hohenzollern'. For Friedländer, diagnosing the Kaiser was a therapeutic act for the German psyche, part of a spiritual revolution that had to follow the political one. ${ }^{77}$ Second, however, Friedländer was also concerned with Wilhelm himself, who had the right to an impartial psychological assessment in the face of moral and legal accusations. ${ }^{78}$ Third, Friedländer argued, a psychological analysis of the personality and role of Wilhelm was crucial to improve relations between Germany and foreign nations. Instead of delivering him to the victors' tribunal, through their own reckoning with their former ruler the Germans would defend their 'national dignity and sovereignty'. Diagnosing Wilhelm would be first step in a longer, international process of exposing the institutions and individuals responsible for the war in every country. The peoples' objective and public judgement over the warmongers, Friedländer believed, would create a powerful precedent, forcing the rulers of all countries to pursue their interests peacefully, in the form of a 'psychologically intensified cultural arms race'. ${ }^{79}$ The catastrophe of the First World War and the collapse of the political order in Europe had created a space of possibilities, in which scientific expertise and humanistic ethos could become the foundations of a pacifist utopia. For Friedländer, as for Auguste Forel, diagnosing the exiled German emperor as mentally ill was to bring to bear psychiatric expertise in the creation of a more enlightened and peaceful post-war order.

\footnotetext{
76 Adolf Friedländer, Wilhelm II.: Versuch einer psychologischen Analyse (Halle/S.: Marhold, 1919), 10-11. Unlike other publications on the topic, Friedländer's booklet was well received by the professional community, see Adolf Hoppe, 'Friedländer, Professor Dr: Wilhelm II: Versuch einer psychologischen Analyse, Halle a. S. 1919', Psychiatrisch-Neurologische Wochenschrift, 21, 13/14 (1919), 93-4; H. Schaefer, 'Ein psychiatrisches Urteil über Wilhelm II', Psychiatrisch-Neurologische Wochenschrift, 21, 27/28, 201-3.

77 See also Adolf Friedländer, Diplomatie, nationale und internationale Psychologie (Halle an der Saale: Nebert, 1919).

${ }^{78}$ Friedländer, op. cit. (note 76), 10.

${ }^{79}$ Ibid., 11.
} 


\section{True Leaders}

During the long nineteenth century, two notions of heredity coexisted. The older one was aristocratic, with centuries-old bloodlines establishing the identity and legitimacy of noble dynasties. For modern medicine, however, bloodlines carried not legitimacy, but hereditary traits that could often be pathological. Instead of charts of high-born ancestors, physicians and early geneticists drew genealogical trees to trace the transmission of pathologies from one generation to another. Michel Foucault (1926-84) placed the shift from one concept to the other against the backdrop of the political rise of the bourgeoisie, whereas more recent research has challenged this view by pointing out that European aristocrats' obsession with the roots of their lineage (as opposed to the purity of the pedigree) was in fact a modern phenomenon that emerged only after the French Revolution. ${ }^{80}$ For writers from Max Nordau to Thomas Mann, the genealogical downward trajectory of degeneration became a powerful metaphor for European civilisation at the turn of the nineteenth century. ${ }^{81}$ Part of what made the psychiatric diagnoses of Wilhelm II politically explosive was that they were situated at the point where both discourses about genealogy overlapped. The alleged mental illness of Wilhelm II raised questions about the heredity of dynastic legitimacy and pathological degeneration at a time when the nation was torn between monarchist, liberal, socialist and right-wing authoritarian notions of governance. In the tumultuous and violent times after the First World War, diagnosing the exiled emperor was a way to discuss Germany's uncertain and contested political future, the right form of leadership, and the qualities of a 'true leader'.

As the anonymous writer in the Irrenrechts-Reform pointed out, the diagnoses of the former emperor were a direct result of the revolution. The eccentricities of Wilhelm II, 'on whom the revolution of 1918 has put a hat' - in place of his crown -, could only now be psychiatrised in the same way as those of a private citizen. ${ }^{82}$ The mental illness of Wilhelm the citizen, however, could retroactively challenge the legitimacy of the rule of Wilhelm the emperor. Moreover, with early twentieth-century psychiatry dominated by a biological and hereditary aetiology of mental illness, the diagnosis could quickly extend to Wilhelm's ancestry, reframing the history of the Hohenzollern dynasty as a tale of progressing degeneration. This was neither a problem for Augustin Cabanès who in his war-time polemics explicitly attacked the Hohenzollern as a 'dynasty of degenerates', nor for several German anti-monarchists after the war. In a letter to Auguste Forel, the German aristocrat, former Reichstag member and pacifist Alexander zu HohenloheSchillingsfürst (1862-1924) - who, ironically, was himself related to the emperor - wrote that the hereditary illness of Wilhelm II provided a compelling argument against hereditary monarchy as such. ${ }^{83}$ Adolf Friedländer made the same point when he claimed that a dynasty as old as the Hohenzollern, which 'the higher it climbed, the more rigorously

\footnotetext{
${ }^{80}$ Michel Foucault, Histoire de la sexualité, 1: La volonté de savoir (Paris: Gallimard, 1976), 164-65; William D. Godsey Jr., Nobles and Nation in Central Europe: Free Imperial Knights in the Age of Revolution, 1750-1850 (Cambridge: Cambridge University Press, 2004), 190-97; 226-39.

81 Pick, op. cit. (note 34).

82 'Wilhelm II. geisteskrank?', op. cit. (note 74), 171.

83 Alexander zu Hohenlohe to Auguste Forel, 8 December 1918, in Auguste Forel, Briefe - Correspondance, 1864-1927, ed. Hans H. Walser (Berne: Huber, 1968), 459-62. On Hohenlohe's view on Wilhelm II, see also Alexander zu Hohenlohe, Aus meinem Leben (Frankfurt am Main: Frankfurter Societäts-Druckerei, 1925), 335-61.
} 
it observed the "purity" of the (legitimate) mixing of its blood, had to decline into degeneration'. ${ }^{84}$ As a symptom of aristocratic inbreeding, the alleged mental illness of the last Hohenzollern emperor became an argument for a republican meritocracy. However, not everyone was willing to discard the central figures of centuries of Prussian and German history. Without questioning the hereditary aetiology of his illness, Forel and others detached the diagnosis of Wilhelm from the rest of the Hohenzollern bloodline by arguing that the pathogenic influence had come from the side of Wilhelm's English mother. ${ }^{85}$

One of the epistemological problems of modern medicine is that, whereas different forms of illness can be observed, described and classified, health remains an elusive concept. ${ }^{86}$ Throughout the history of medicine, this gap often was a gateway to utopian thinking, as health was imagined as more than just an absence of illness, but as an ideal that had yet to be achieved. In the diagnoses of Wilhelm II, the idea of a positive definition of health became an argument about political leadership, based on the juxtaposition of the image of the sick emperor and an ideal, healthy leader.

As Ernesto Lugaro had recognised, diagnosing the Kaiser implied a counterfactual reading of recent history. If Wilhelm's mental illness had caused the cataclysm of 1914, how would a sane person have dealt with the crisis? Several of the authors who contributed to the debate about the mental state of the former emperor tackled this question. The ultranationalist publisher Julius Lehmann remained vague when he claimed that the failure of Wilhelm had shown that the state had to be led by a 'real man' ${ }^{87}$ For the socialist Auguste Forel, the benchmark of political rationality was the former Reich Chancellor Otto von Bismarck, who had orchestrated the unification of Germany and maintained the balance of power by skilfully creating a system of interlocking treaties between the main European powers, and who, in Forel's imagination, could have averted the war. ${ }^{88}$ A strikingly similar argument was also made by Paul Tesdorpf, who wrote that 'Wilhelm II was a pathological degenerate, a lunatic; Bismarck was mentally sane, a complete human being (Vollmensch) in the highest sense of the word' ${ }^{89}$ While Wilhelm II was diagnosed as mentally unfit to rule, Bismarck became the model for a hoped-for 'true leader' ${ }^{90}$ Obviously, Bismarck, who had died in 1898, would not be able to return to save the German nation. Nevertheless, the juxtaposition of the irrational Wilhelm and the rational Bismarck resonated with the resurgence of the glorification of the 'Iron Chancellor', ${ }^{91}$ as well as with more general concerns about political leadership. Germany after the First World War was in search of a leader, and the diagnoses of Wilhelm II were part of this discourse. ${ }^{92}$

\footnotetext{
84 Friedländer, op. cit. (note 76), 13. The same argument can also be found in 'Wilhelm II. geisteskrank?', 171.

${ }^{85}$ Forel, 'Verhängnisse I', op. cit. (note 45); Schaefer, op. cit. (note 76), 203.

${ }^{86}$ Cornelius Borck, Medizinphilosophie zur Einführung (Hamburg: Junius, 2016), 69-72.

${ }^{87}$ Lehmann, op. cit. (note 64), 5.

${ }^{88}$ Forel, 'Verhängnisse I', op. cit. (note 45) Bismarck's own assessment of the personality of Wilhelm II was only published in 1921: Otto von Bismarck, 'Kaiser Wilhelm II. (1890/1921)', in Kohlrausch, Samt und Stahl, op. cit. (note 2), 57-82.

89 Tesdorpf, Die Krankheit, op. cit. (note 56), 33.

90 The same argument was also made by other German psychiatrists in their diagnoses of the 'psychopaths' who allegedly had led the revolution, see Eugen Kahn, 'Psychopathen als revolutionäre Führer', Zeitschrift für die gesamte Neurologie und Psychiatrie, 52, 1 (1919), 90-106; Emil Kraepelin, 'Psychiatrische Randbemerkungen zur Zeitgeschichte', Süddeutsche Monatshefte, 16 (1919), 171-83; Freis, op. cit. (note 7).

${ }^{91}$ Robert Gerwarth, The Bismarck Myth: Weimar Germany and the Legacy of the Iron Chancellor (Oxford: Clarendon Press, 2005), 30-44.

92 Thomas Mergel, 'Führer, Volksgemeinschaft und Maschine: Politische Erwartungsstrukturen in der Weimarer Republik und dem Nationalsozialismus 1918-36', in Wolfgang Hardtwig (ed.) Politische Kulturgeschichte der Zwischenkriegszeit 1918-39 (Göttingen: Vandenhoeck \& Ruprecht, 2005), 91-128. On the emergence of
} 
Where this development was headed is visible in a relatively late contribution to the debate about the mental state of Wilhelm II, published in 1927 by the physician Ernst Müller, author of a number of 'pathographic' studies of Roman emperors. ${ }^{93}$ Müller's 'historical and psychiatric study' of Wilhelm and the Hohenzollern dynasty was a somewhat uneven book, staggering between political arguments about the monarchy and the war, listings of the 'good' and 'bad' qualities of Wilhelm and lengthy discussions of the Hohenzollerns' physiognomy as depicted in paintings and on coins. Müller could quote from a plethora of biographical and autobiographical works about Wilhelm II that had appeared in the early 1920s, among them Emil Ludwig's (1881-1948) heavily psychologising 1925 best-seller Wilhelm der Zweite. ${ }^{94}$ Müller arrived at the same conclusions as earlier diagnosticians. Wilhelm, he wrote, was a 'high-bred degenerate and the diagnosis also includes psychopathy and neurasthenia'. ${ }^{95}$ Yet, the political context had since shifted. The question of war guilt, Kriegsschuldfrage, which had framed the earlier debates, appeared only as Kriegsschuldlüge, the false accusation of war guilt. ${ }^{96}$ Müller was not interested in why Wilhelm had entered the war, but only in why Germany had lost. Also, as the calls for his extradition to a war crimes tribunal had lapsed into silence, exonerating the Kaiser became less important. Wilhelm's failure, Müller believed, could be explained through heredity and environment, but it could not be forgiven. ${ }^{97}$

Ernst Müller's diagnosis of Wilhelm II was an assessment of his leadership during the war, as well as an argument about Germany's political future. Others had blamed Wilhelm for his authoritarian tendencies and had seen them as symptoms of delusion and megalomania; in Müller's eyes, the Kaiser had not been ruthless and authoritarian enough. With stronger nerves, Wilhelm might have 'ruled as a dictator', won the war through massive aerial bombardments of Rome and London, quashed any signs of mutiny and revolution, and returned home at the head of his victorious troops. ${ }^{98}$ Müller's accusation that Wilhelm's weak nerves had lost the war echoed the wartime rhetoric about the mental strength of the German nation as a prerequisite for victory. It implicitly made the emperor the most prominent of the hundreds of thousands of 'war neurotics', soldiers who had suffered mental breakdown in the face of the strains and horrors of industrialised warfare. After the war, right-wing psychiatrists had blamed these 'weak-willed' soldiers for the defeat; Müller applied the same argument to the exiled emperor. ${ }^{99}$

leadership and the figure of Wilhelm II in post-war Germany, Kohlrausch, Der Monarch im Skandal,op. cit. (note 19), 414-32. For a broader perspective, see also Yves Cohen, Le siècle des chefs: Une histoire transnationale du commandement et de l'autorité (1890-1940) (Paris: Amsterdam, 2013).

93 Ernst Müller, Wilhelm II.: Eine historische und psychiatrische Studie (Gotha: Vogt, 1927); Ernst Müller, 'Die Regenten des Julisch-Claudischen Kaiserhauses in historischer, genealogischer und psychiatrischer Beleuchtung', Allgemeine Zeitschrift für Psychiatrie und psychisch-gerichtliche Medizin, 70, 4 (1913), 575-97; Ernst Müller, 'Die Kaiser Domitian, Commodus, Caracalla und Elagabal: Ein Beitrag zur Frage des Cäsarenwahnsinns', Allgemeine Zeitschrift für Psychiatrie und psychisch-gerichtliche Medizin, 71, 2 (1914), 271-88.

${ }^{94}$ Ludwig Emil, Wilhelm der Zweite (Berlin: Rowohlt, 1925).

95 Müller, op. cit. (note 93), 76.

96 Ibid., 39.

97 Ibid., 78.

98 Ibid., 71-4.

99 Paul Lerner, Hysterical Men: War, Psychiatry, and the Politics of Trauma in Germany, 1890-1930 (Ithaca, NY: Cornell University Press, 2003); Hans-Georg Hofer, Nervenschwäche und Krieg: Modernitätskritik und Krisenbewältigung in der österreichischen Psychiatrie (1880-1920) (Vienna: Böhlau, 2004); Jason Crouthamel, The Great War and German Memory: Society, Politics and Psychological Trauma, 1914-45 (Exeter: University of Exeter Press, 2009). 
Wilhelm had failed, and what Germany needed now was a leader to guide the nation out of its misery. Müller's vision of the future led him where the debate about the mental state of Wilhelm II had begun more than three decades earlier: to Tacitus. His liberator germaniae, who like Arminius would lead the Germans to glory, was Paul von Hindenburg (1847-1934), Chief of the General Staff during the war and German President since 1925. However, the apparent degeneration of the Hohenzollerns that had led to Wilhelm's failure as a wartime leader had wider implications, Müller argued. To prevent the return to power of the old and degenerated aristocracy, a new concept of nobility, defined by biology and eugenics, would have to be introduced. Germany's future leaders would be 'men with blonde hair, slender heads, blue eyes, of good intellect, of noble sentiment, of lean build, self-confidence and restraint and elegant gait'. ${ }^{100}$ In the three decades from Quidde to Müller, the mind of Wilhelm II had been diagnosed in the name of liberalism, democracy, a socialist world-society, to support the allied warfare against Germany, in the defence of monarchy and finally for the racialist authoritarianism that would soon become the dominant force in German politics.

\section{Conclusion}

Wilhelm II was not the last political figure to be diagnosed for mental defects in public and in absentia. Numerous examples from the last hundred years come to mind, and I will confine myself to mention very briefly some of the more prominent cases. The man whom many Germans identified as the 'true leader' that Wilhelm had failed to be is certainly the most notorious example. The ideological fervour and ruthlessness of Adolf Hitler and other prominent National Socialists were perceived as signs of mental abnormality by many contemporaries; so much in fact that the American and British governments tasked psychiatrists and psychoanalysts to unravel the mystery of the 'Nazi mind' during the Second World War. ${ }^{101}$ After 1945, some German psychiatrists seized on the same tropes that had already circulated after the last war, arguing that the 'Führer' had probably been a 'psychopath' and that the wilful participation of countless Germans in the crimes of the Nazi regime had been caused by 'mass suggestion'. ${ }^{102}$ Even more than in the case of Wilhelm II, such diagnoses implied an exculpation and even self-victimisation, of the German nation. Erwin Stransky (1877-1962), a Viennese psychiatrist who in the aftermath of the First World War had already published an ambitious manifesto for the expansion of psychiatrists' expertise into every aspect of politics and society, arrived at the conclusion that instead of diagnosing the psychopaths afterwards, preventive action had to be taken before it was too late. ${ }^{103}$ The United Nations, or a prospective European Union, Stransky argued in 1952, would have to appoint a commission of experienced psychiatrists to screen political and economic leaders for signs of dangerous mental illness to prevent the next catastrophe. ${ }^{104}$

\footnotetext{
100 Müller, op. cit. (note 93), 80. The source of Müller's ideas was Hans F.K. Günther, Adel und Rasse (Munich: Lehmann, 1927); Alexandra Gerstner, Neuer Adel: Aristokratische Elitekonzeptionen zwischen Jahrhundertwende und Nationalsozialismus (Darmstadt: Wissenschaftliche Buchgestellschaft, 2008).

${ }^{101}$ Daniel Pick, The Pursuit of the Nazi Mind: Hitler, Hess, and the Analysts (Oxford: Oxford University Press, 2012).

102 Karl Bonhoeffer, 'Führerpersönlichkeit und Massenwahn', in Jörg Zutt, Erwin Straus and Heinrich Scheller (eds), Karl Bonhoeffer: Zum hundertsten Geburtstag am 31. März 1968 (Berlin: Springer, 1969), 108-14.

103 Erwin Stransky, 'Angewandte Psychiatrie: Motive und Elemente zu einem Programmentwurf', Allgemeine Zeitschrift für Psychiatrie und psychisch-gerichtliche Medizin, 74, 1-3 (1918), 22-53.

${ }^{104}$ Erwin Stransky, Psychopathie und Staatsführung (Vienna: Urban \& Schwarzenberg, 1952).
} 
However, even the assertive American psychiatrists of the Cold War would decide that this kind of politicisation of their expertise was a threat to the integrity of their profession. In 1964, the magazine Fact polled psychiatrists about their assessment of the mental state of the controversial Republican senator and presidential candidate Barry Goldwater (1909-88). As far as the sheer number of diagnoses was concerned, 1964 set a record. Of the 2417 psychiatrists who responded, 1189 were convinced that Goldwater was mentally unfit to serve as president, describing him as 'megalomaniac', 'grossly psychotic', 'schizophrenic' and as suffering from a 'narcissistic personality disorder', without any previous personal examination. ${ }^{105}$ The case set an important legal and ethical precedent: Goldwater brought in a successful libel suit against the magazine and its publisher, and both the American Medical Association and the American Psychiatric Association (APA) condemned the Fact poll. In Section 7.3 of its first ethics code from 1973, informally known as the 'Goldwater rule', the APA eventually stated that it was unethical for its members to offer professional opinions about public figures without examination and proper authorisation. ${ }^{106}$ In the following decades, psychiatrists and other mental health care professionals by and large stuck to the rule.

Against the background of the recent resurgence of nativist right-wing populism, however, the genre of psycho-political diagnosis flourishes again. Shocked by increasingly aggressive authoritarianism across the world, anti-immigrant violence and a repugnant campaign culminating in a Trump Presidency, numerous journalists and intellectuals have resorted to psychiatric and psychoanalytic concepts to make sense of the emotional dynamics of present-day politics. The apparent eccentricity of the protagonists and the fact that they and their followers routinely employ an obscurantist 'post-factual' rhetoric that blurs and distorts not only specific facts, but also the underlying notion of truth and rationality as such, add to the sense that only the diagnostic concepts of clinical psychiatry can help to understand what is going on. ${ }^{107}$ During the first year of his presidency, speculations about the mental state of Donald J. Trump and the nation have found their way into major US newspaper and magazines, as well as into best-selling books. ${ }^{108}$ To historians, the present often bears an uncanny resemblance to the past. It is not only the structural dynamics that seem to echo earlier periods, but also the recurring tropes of the debate. The popular historian Tom Holland was struck by the 'fascinating parallels' between Trump and Caligula. ${ }^{109}$ Again, the way from Roman antiquity to Wilhelmine Germany is shorter than one might think. Shortly before the 2016 election, Christopher Clark and Andrew Preston urged the readers of New Statesman to 'beware the Kaiser chiefs', pointing out the psychological similarities between the forty-fifth President of the United States and the last Hohenzollern emperor. ${ }^{110}$ One year later, political scientist

105 Richard A. Friedman, 'How a Telescopic Lens Muddles Psychiatric Insights', New York Times (24 May 2011), D5.

106 John Martin-Joy, 'Goldwater v. Ginzburg', American Journal of Psychiatry, 172, 8 (2015), 729-30.

107 Peter Pomerantsev, Nothing is True and Everything is Possible: Adventures in Modern Russia (London: Faber \& Faber, 2015).

108 Allen Frances, Twilight of American Sanity: A Psychiatrist Analyzes the Age of Trump (New York: Morris, 2017); Bandy X. Lee, The Dangerous Case of Donald Trump: 27 Psychiatrists and Mental Health Experts Assess a President (New York: St. Martin's, 2017).

${ }^{109}$ Mark Brown, 'Donald Trump has “fascinating parallels” with Caligula, says historian', The Guardian (1 June 2016).

${ }^{110}$ Christopher Clark and Andrew Preston, 'Beware the Kaiser Chiefs', New Statesman (27 October 2016). 
Stephen M. Walt made a similar point when he warned that the 'Donald Trump-Kaiser Wilhelm parallels are getting scary'. ${ }^{111}$

As for now, I would rather leave the present to future historians, and briefly point to some of the criticism that has been raised. In Britain, the editors of Lancet Psychiatry reminded their readers to refrain from using psychiatric concepts to attack political opponents: 'Perhaps the most that psychiatrists can manage is to realise that while they might not wield scalpels, handle sources of radiation, or have access to cytotoxic drugs, they employ language and concepts that are potentially hazardous in their misuse. ${ }^{112}$ On the other side of the Atlantic, journalists and mental health professionals took a renewed interest in the lessons of the Goldwater affair, weighing the APA's attempt to protect the integrity of the discipline against psychiatrists' moral and political responsibilities. ${ }^{113}$ Jerome Kroll and Claire Pouncey criticised the professional politics behind the Goldwater rule, arguing that the attempt to 'prevent individual psychiatrists from misrepresenting or embarrassing the psychiatric profession' came at 'the expense of personal, professional, or social values'. ${ }^{114}$ Others, however, disagreed with the 'armchair Freuds' analysing the then-candidate from a distance, not in order to defend Trump, but, on the contrary, due to fears that this kind of diagnosis risked 'taking politics and ethics out of the equation'. Wired author Nick Horton was rightly concerned that using allegations of mental illness to discredit Trump and other political figures might backfire by reinforcing stereotypes and adding to the stigmatisation of actual mental patients. ${ }^{115}$

The historical diagnoses of Wilhelm II may serve as another cautionary tale. At a time when European and German politics were highly personalised, polarised and in upheaval, diagnosing the Kaiser as mentally ill appeared to be a powerful and popular argument. Psychiatry offered a conceptual framework that made it possible to make sense of seemingly irrational dynamics in politics without the need for an in-depth analysis, and could be used to ward off, shift and re-allocate the political responsibility for the catastrophe of the First World War. However, psychiatric diagnoses were a rather unwieldy weapon in wartime and post-war political debates. The idea that Wilhelm was mentally ill could be used to support almost any political agenda; it could be directed against the exiled emperor, or used in his defence. As the psychiatrist and psychotherapist Arthur Kronfeld (1886-1941) reminded his colleagues in 1921, psychiatry was a normative science, but its norms were not the same as those of politics and society. ${ }^{116}$ Adopting psychiatric concepts of illness and health to make political arguments about the situation and the future of the German nation after the First World War was compelling, but these concepts came with a momentum of their own.

\footnotetext{
111 Stephen M. Walt, 'The Donald Trump-Kaiser Wilhelm parallels are getting scary', Foreign Policy (12 October 2017), http://foreignpolicy.com/2017/10/12/the-donald-trump-kaiser-wilhelm-parallels-are-getting-scary/.

112 'Medicalisation and its Discontents', Lancet Psychiatry, 3, 7 (2016), 591.

113 Benedict Carey, 'Analyzing Trump', New York Times (16 August 2016), D1.

114 Kroll Jerome and Pouncey Claire, 'The Ethics of APA's Goldwater Rule', Journal of the American Academy of Psychiatry and the Law, 44, 2 (2016), 226-235: 233.

115 Nick Stockton, 'Stop Trying to Psychoanalyze Donald Trump', Wired (5 August 2016), https://www.wired. com/2016/08/stop-trying-psychoanalyze-donald-trump/.

116 Arthur Kronfeld, 'Eine Bedenklichkeit der "angewandten" Psychiatrie', Zeitschrift für die gesamte Neurologie und Psychiatrie, 65 (1921), 364-7.
} 